\title{
ASSESSMENT OF ANAEROBIC ENDURANCE BASED ON SELECTED BIOCHEMICAL PARAMETERS IN 400 M/400 M HURDLES MALE ATHLETES
}

\author{
Anna Stolecka-Warzecha, ${ }^{\mathrm{C}, \mathrm{D}}$ Tomasz Kaczmarczyk, ${ }^{\mathrm{B}}$ Aleksandra Żebrowska ${ }^{\mathrm{A}, \mathrm{E}}$ \\ Department of Physiology, The Jerzy Kukuczka Academy of Physical Education in Katowice, Poland \\ A Study Design; ${ }^{\mathrm{B}}$ Data Collection; ${ }^{\mathrm{C}}$ Statistical Analysis; ${ }^{\mathrm{D}}$ Manuscript Preparation; ${ }^{\mathrm{E}}$ Funds Collection \\ Address for correspondence: \\ Anna Stolecka-Warzecha \\ The Jerzy Kukuczka Academy of Physical Education in Katowice, Department of Physiology \\ Mikołowska 72A, 40-065 Katowice, Poland. \\ E-mail: annastolecka@interia.pl
}

\begin{abstract}
Ahstract. The ongoing development of the modern society may also be easily noticed in sports. Currently, to be able to compete at the highest level at major sporting events, it is essential to conduct scientific research to estimate the individual potential and skill level of an athlete. The aim of this study was to assess the anaerobic endurance in men competing in the running events of $400 \mathrm{~m} / 400 \mathrm{~m}$ hurdles based on the estimation of maximum power, as well as selected biochemical and physiological parameters measured in a cardiac stress test at a supramaximal intensity. Seven athletes participated in the study and were subjected to a modified version of the Wingate test (Bar-Or, Dotan, Inbar, 1997; Bar-Or, Inbar, Skinder, 1996) which involved performing three runs of a 12-second endurance test on a cycloergometer at short intervals. This modification of the test allowed a more precise observation and a better understanding of the physiological and biochemical changes that decrease the efficiency as a result of repeated physical effort, which may significantly affect the assessment of the preparation of an athlete, and thus the assessment of the training process.

The most significant changes in the course of the conducted study were observed in the values of the following biochemical parameters: glucose levels, acid-base balance of the blood and lactate levels.
\end{abstract}

KeV WOrlls: exercise physiology, anaerobic endurance, athletics

\section{Introduction}

Athletics is one of the oldest and the most diverse sport disciplines. The amount and intensity of the exerted work is determined by event type. The $400 \mathrm{~m}$ and $400 \mathrm{~m}$ hurdles races employ speed, endurance and strength in equal amounts, and the $400 \mathrm{~m}$ hurdles races also require proper technique. An equal and simultaneous combination of all the aforementioned elements during $45-50$ seconds is usually very difficult due to the quickly increasing fatigue, therefore the final result mostly depends on the athlete's speed endurance characterized by anaerobic metabolic processes occurring in the body (Iskra, 2001).

Physical endurance is the ability to exert hard or long-lasting physical exercise involving large muscle groups. The term also embraces the tolerance to variations in homoeostasis and the ability of quick balance recovery 
once the physical activity has finished (Górski, 2006; Kozłowski, Nazar, 1995). According to prof. Kubica, physical endurance may be defined as the ability demonstrated by the organism to exert a particular type of physical work, expressed as the maximum level of physical capabilities and rapid restitution processes (Kubica, 1995). Among the factors determining physical endurance, there are: aerobic energetic potential (aerobic endurance), anaerobic energetic potential (anaerobic endurance), anthropological and biomechanical characteristics (age, sex, body height, body weight), motoric abilities (strength, speed, resistance), motivation and physical endurance test conditions (Malarecki, 1981; Zając, Wilk, Poprzęcki, Bacik, 2009). As is mentioned above, in the $400 \mathrm{~m}$ and $400 \mathrm{~m}$ hurdles races, the key factor determining the result is the efficiency of anaerobic metabolic processes occurring in the body, in which adenosine triphosphate (ATP) is produced via two energy processing systems, anaerobic/ lactate-independent and anaerobic/lactate-dependent, supported by a third mechanism: aerobic/lactate-dependent (Boobis, Cheetham, 1986; Greenhaff, Hultman, Harris, 1993). During a 400 m/400 m hurdles race, the first metabolic processes employed by the human body are those endowed with the highest power index, yielding the fastest results. These processes use ATP accumulated in the muscles and phosphocreatine. During the hydrolysis of ATP accumulated in the muscles, the last phosphate residue is detached which yields adenosine diphosphate, inorganic phosphate and energy. ATPase is the enzyme that catalyses this reaction. PCr decomposition is mediated by creatine kinase (CK) and its final products are creatine, inorganic phosphate and the liberated energy. The estimates of the quantity of both energetic compounds in the human body are $2-4 \mathrm{mmol} \cdot \mathrm{kg}^{-1}$ for muscle ATP and $20 \mathrm{mmol} \cdot \mathrm{kg}^{-1}$ for phosphocreatine in hydrated muscle tissue. The amount of the substrates is sufficient to effectively exert work for as little as the first few seconds of exercise. Importantly, during the use of those energetic substrates, blood levels of lactic acid increase only insignificantly and do not exceed the value of $3 \mathrm{mmol} \cdot \mathrm{kg}^{-1} \cdot \mathrm{s}^{-1}$ (Heck, Schulz, Bartmus, 2003). To maintain an appropriate level of intensity once the anaerobic/lactate-independent processes have become ineffective, the body starts to produce energy using the anaerobic/lactate-dependent processes. The substrates in the ATP resynthesis via anaerobic glycolysis are glycogen or glucose (Jaskólska, Jaskólski, 2006; Wołkow, Jarużnyj, 1986).

Every mole of glucose involved in the reaction yields 2 moles of ATP. If glycogen-derived glucose is the energetic substrate used, 3 moles of ATP are formed. The difference stems from the use of one mole of glucose in the phosphorylation process producing glucose-6-phosphate. With no involvement of oxygen in the reaction, pyruvate, the final product of the reaction, is converted into lactate. Subsequently, it accumulates in the muscle tissue and then diffuses into the blood (Górski, 2006). The highest considered level of blood acidification by lactate is $20 \mathrm{mmol} \cdot \mathrm{L}^{-1}$. However, in athletes competing in sprints, particularly in the $400 \mathrm{~m} / 400 \mathrm{~m}$ hurdles races, those values might even reach $25 \mathrm{mmol} \mathrm{L}^{-1}$ (Heck, Schulz, Bartmus, 2003). The third and last process of energy production involved during the $400 \mathrm{~m} / 400 \mathrm{~m}$ hurdles races is aerobic glycolysis. When pyruvate is formed, in the presence of oxygen it undergoes decarboxylation yielding acetyl CoA. The coenzyme subsequently enters the Krebs cycle, in which the necessary energy is formed as 12 ATP molecules per cycle and 36 ATP molecules per one mole of glucose (Traczyk, 2002). Energy production in aerobic glycolysis is the slowest of the three processes employed during the race, yet it is also the longest-lasting one. 


\section{Material and methods}

The entire scientific procedure was approved by the Bioethics Committee for Scientific Research at the Jerzy Kukuczka Academy of Physical Education in Katowice before the start of the study on 11th March 2012. The group enrolled in the study consisted of 7 athletes (men) competing in the $400 \mathrm{~m}$ and/or $400 \mathrm{~m}$ hurdles races. During the procedures including the determination of power and anaerobic capacity, as well as the measurements of body height, weight and composition, arterial blood pressure and heart rate, noninvasive measurement methods were used (Monark Ergomedic 874 E cycloergometer, MCE 5.1 software, InBody 220 Body Composition Analyzer, POLAR Sport tester, GOMED JD-1005 blood pressure meter).

To determine the changes in the processes involved in acid-base balance $(\mathrm{pH})$, the proportion of gases and the level of acidification by lactate, and to verify blood glucose levels, two invasive measurement methods were used, based on taking capillary blood samples from a fingertip and its subsequent biochemical analysis (Siemens Bayer RapidLab 248 blood pH and gas analyser; UV.1209 SHIMADZU UV spectrophotometer; Boehringer-Mannheim enzymatic procedure; HemoCue glucose analyser).

In the conducted study, the athletes participated in an anaerobic power assessment test. The test was composed of three 12 seconds long runs with 5 minute breaks between runs. Pedal load of the cycloergometer was adjusted individually for every subject and corresponded to $75 \mathrm{~g} / 1 \mathrm{~kg}$ b.w. In every run, the subject exerted maximum power physical exercise interspersed by intervals of passive rest. Every anaerobic test was preceded by a freely selectable, individual warm-up on a cyclometer, lasting 5-6 minutes. Before the first run and after each of them, the subjects underwent precisely defined measurements.

In the conducted studies, in order to analyse the obtained results, the STATISTICA 8.0 software was used. The statistical analyses included: ANOVA, Tukey's post hoc multiple comparison test and Pearson's correlation. The threshold of statistical significance of the results was set at $p<0.05$.

\section{Results}

\section{Group specifications}

The studied group was characterized by similar age (21.9 \pm 2.52 years) and BMI value (22.2 \pm 1.08$)$, while some differences were noted in the values of body height $(181 \pm 6.95 \mathrm{~cm})$ and weight $(72.6 \pm 4.66 \mathrm{~kg})$. Moreover, the studied group had a similarly low quantity of adipose tissue $(5.9 \pm 1.57 \mathrm{~kg})$, but demonstrated significant variations in the values of fat-free body mass $(66.7 \pm 5.42 \mathrm{~kg})$, total body water $(48.8 \pm 3.88 \mathrm{~kg})$ and muscle tissue content $(38.2$ $\pm 3.27 \mathrm{~kg})$.

In the ergometric tests, the subjects performing three runs of a 12-second test were subjected to measurements aimed at assessing the following absolute values: maximum power [W/kg], mean power [W/kg] and mean exerted work $[\mathrm{J} / \mathrm{kg}]$.

\section{Comparison of ergometric values from 3 runs}

The ANOVA method did not reveal any significant influence of repeated supramaximal exercise on maximum power $(F=2.54 ; p<0.106)$ and mean power $(F=2.35 ; p<0.124)$ values. However, a strict correlation between the maximum anaerobic power and mean power of exercise in each run was revealed: $\operatorname{Ex}_{1}(r=0.893 ; p<0.007)$, Ex 2 $(r=0.808 ; p<0.028)$ and $\operatorname{Ex}_{3}(r=0.881 ; p<0.009)$. 
Table 1. Results of ergometric measurements from all three runs

\begin{tabular}{lcccccc}
\hline \multicolumn{1}{c}{$(\mathrm{n}=7)$} & Mean & Max. & Min. & SD & CV & Kurtosis \\
\hline Max power [W/kg] & & & & & & \\
Ex $_{1}$ & 12.39 & 13.5 & 11.6 & 0.641 & 5.178 & 0.325 \\
Ex $_{2}$ & 12.01 & 12.9 & 11.5 & 0.543 & 4.519 & -0.823 \\
Ex $_{3}$ & 11.66 & 12.5 & 10.8 & 0.624 & 5.354 & -0.908 \\
\hline Mean power [W/kg] & & & & & & \\
Ex & 10.53 & 11.3 & 10.0 & 0.492 & 4.676 & -1.236 \\
Ex $_{2}$ & 10.29 & 11.0 & 9.8 & 0.422 & 4.102 & -0.265 \\
Ex $_{3}$ & 9.97 & 10.9 & 9.2 & 0.525 & 5.265 & 1.409 \\
\hline Exerted work [J/kg] & & & & & & \\
Ex & 126.43 & 136.0 & 120.0 & 5.884 & 4.654 & -0.852 \\
Ex $_{2}$ & 123.14 & 131.0 & 118.0 & 4.845 & 3.934 & -0.792 \\
Ex $_{3}$ & 119.86 & 130.0 & 111.0 & 5.843 & 4.875 & 1.363 \\
\hline
\end{tabular}

\section{Results of biochemical tests}

In order to obtain biochemical parameters from the studied group, the athletes were subjected to the measurements of: blood glucose, blood lactate and acid-base balance of the blood $(\mathrm{pH})$. Each parameter was determined before the first anaerobic test, in order to obtain the baseline values (BL), and then in the 4th minute of restitution after each concluded run, in order to obtain the post-exercise values (Ex $\left.1, E_{2}, E x_{3}\right)$.

The lowest mean value of blood glucose levels obtained in the studied group was the baseline value 91 \pm 6.73 [mg/dl]. Physical exercise caused an increase in the mean blood glucose levels. Blood glucose levels were $97.85 \pm 9.34$ [mg/dl] after the first run, $100.71 \pm 10.05[\mathrm{mg} / \mathrm{dl}]$ after the second run, and $105.43 \pm 10.20$ [mg/dl] after the third run of the test (Figure 1).

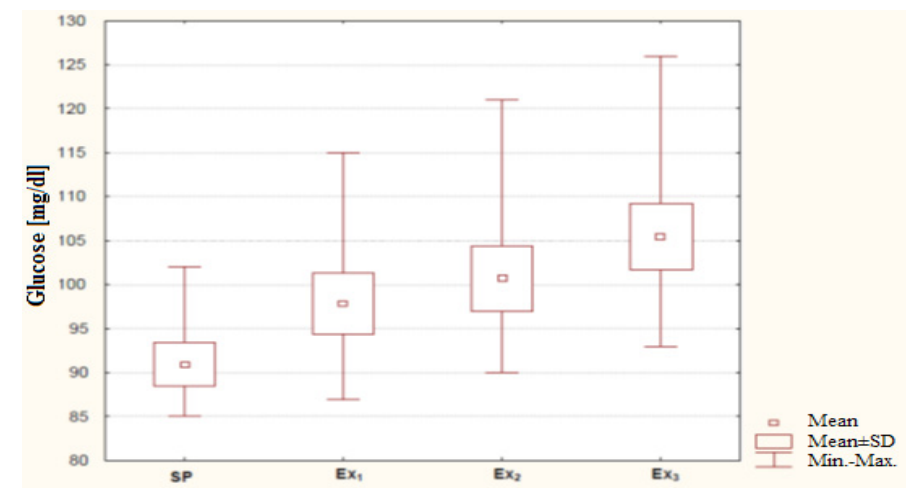

Figure 1. Graphical representation of the obtained blood glucose values 
The analysis of variance indicated a significant effect of repeated supramaximal exercise on the increase in blood glucose levels $(F=3.02 ; p<0.05)$. Statistical significance of the increase in blood glucose levels compared to the baseline value was revealed only for $\mathrm{Ex}_{3}$, with $p<0.034$ (Figure 1).

The analysis of variance indicated a significant effect of repeated supramaximal exercise on the increase in blood lactate levels $(F=231.87 ; p<0.001)$. Moreover, significant differences were found in the following result pairs: $B L$ vs. $E x_{1}, B L$ vs. $E x_{2}$, and $B L$ vs. $E x_{3}$, with $p<0.001$, as well as in the following pairs: $E x_{1}$ vs. $E x_{2}, E x_{1}$ vs. Ex $x_{3}$, and $E x_{2}$ vs. Ex $x_{3}$, with $p<0.004$ (Figure 2).

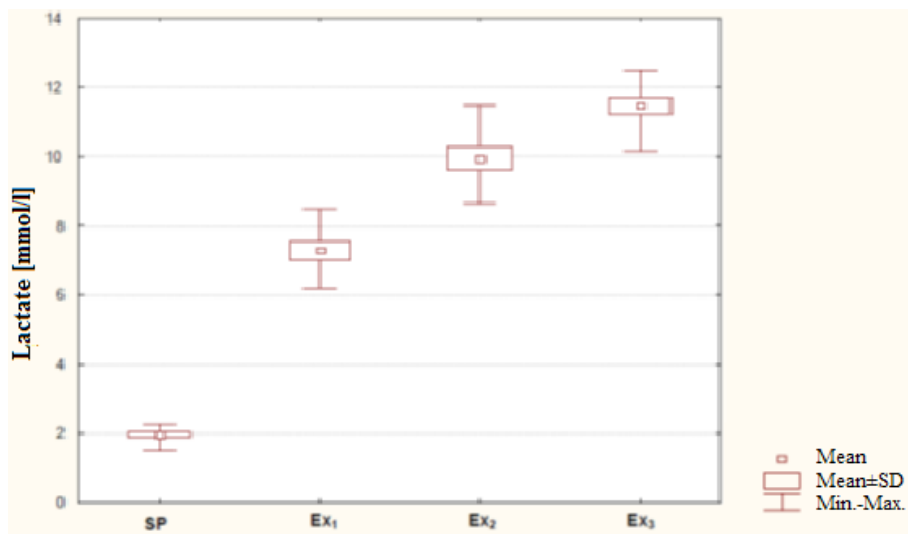

Figure 2. Graphical representation of the obtained blood lactate values



Figure 3. Graphical representation of the obtained blood pH values 
The analysis of variance indicated a significant effect of repeated supramaximal exercise on the decrease in blood acid-base balance $(F=106.11, p<0.001)$. Moreover, significant differences were found in the following result pairs: $B L$ vs. $E x_{1}, B L$ vs. $E x_{2}$, and $B L$ vs. $E x_{3}$, with $p<0.001$, as well as in the following pairs: $E x_{1} v s$. $E x_{2}$, Ex 1 vs. $E x_{3}$, and $\mathrm{Ex}_{2}$ vs. $E x_{3}$, with $p<0.02$ (Figure 3).

\section{The coursese of post-exerecise restitution}

In the conducted study, arterial blood pressure and heart rate were subjected to a thorough analysis. Both parameters were measured at baseline and in the restitution period, after each of the test runs performed. As for arterial blood pressure, the mean baseline values were $124 \pm 7.48$ [mm Hg] for SBP and $83 \pm 7.08$ [mm Hg] for DBP. As the subsequent endurance tests were conducted, the obtained values were slightly different. Compared to the baseline values, an increase was observed in systolic blood pressure, while a decrease was observed in diastolic blood pressure, reaching the mean values of $131 \pm 9.76[\mathrm{~mm} \mathrm{Hg}]$ and $76 \pm 8.62[\mathrm{~mm} \mathrm{Hg}$ ], respectively, at the end of the experiment (Figure 4).

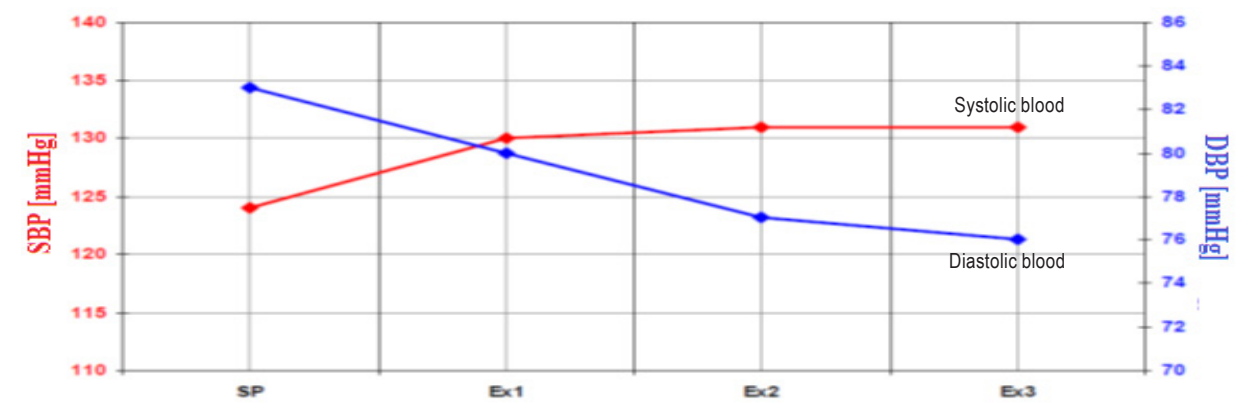

Figure 4. Graphical representation of blood pressure values obtained at baseline $(B L)$ and after each test run $\left(\mathrm{Ex}_{1}, \mathrm{Ex}_{2}, \mathrm{Ex}_{3}\right)$

As for heart rate, the mean baseline value was $66 \pm 9.46$ [BPM]. The highest heart rate values in the studied group were obtained immediately after each of the anaerobic test runs (Ex $1: 151 \pm 9$ [BPM], Ex $2: 162 \pm 7$ [BPM], Ex: $161 \pm 10$ [BPM]), and decreased significantly afterwards. The lowest HR values were noted between the $3 \mathrm{rd}$ and the 4 th minute of restitution after the first (110 \pm 19 [BPM]) and the second (124 \pm 22 [BPM]) test run. After that period, heart rate increased until another endurance test run. In the case of restitution after the third run, the heart rate values continued to decrease until minute 5 (110 \pm 19 [BPM]). Detailed graphical representation of the course of all three restitution periods is presented in Figure 5 .

The analysis of variance of the course of all restitution values indicated a significant difference only between the second and the third restitution period in the 5 th minute of measurement $(F=5.50 ; p<0.02)$. 


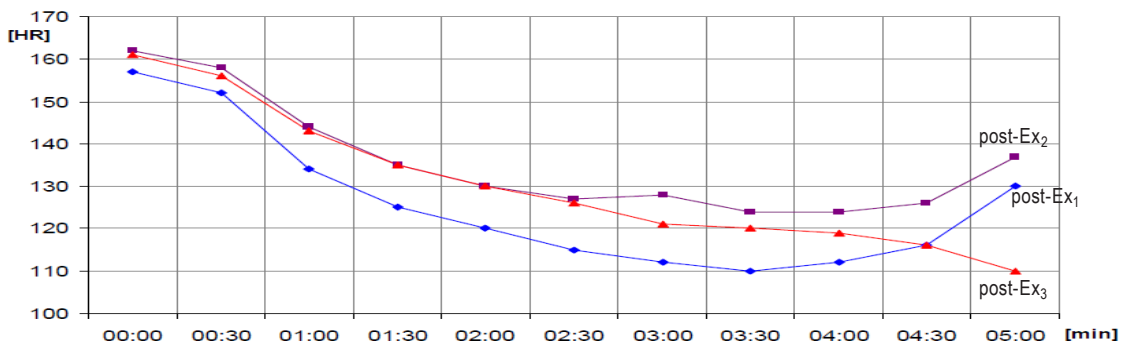

Figune 5. Graphical representation of the mean course of blood pressure changes after each endurance test run

\section{Discussion}

Endurance tests conducted among athletes competing in different disciplines

of sport are growing in popularity as a tool to control training level and plan training load. Increased energetic potential of skeletal muscles is one of the main effects of training in speed/endurance sports. In the first phase of a run, phosphagenic processes and anaerobic glycolysis are used, enabling the athlete to exert and continue the exercise at the intensity close or equal to maximum power. In the second phase, aerobic glycolysis dominates and its use enables the athlete to continue the exercise despite a significant decrease in power.

\section{Effect of speed training on speed endurance}

In the group of athletes competing in the $400 \mathrm{~m} / 400 \mathrm{~m}$ hurdles races, high values of maximum power were detected. The obtained values were similar to those presented in previous studies conducted in athletes competing in sprints: 100, 200 and 400 m races (Gabryś, 2000; Gabryś, Szmatlan-Gabryś, 1997; Kosendiak, Habiniak, Markowski, 1999). The well documented effect of intense speed training on adaptive changes in the muscular system results in increases in muscle mass via hypertrophy, which occurs mostly in the fast twitch muscle fibre types $A$ and $X$. The phenomenon involves increases in muscle diameter and the content of contractile and cytoplasmic proteins in the muscle (Zając, Wilk, Poprzęcki, Bacik, 2009). The adaptive processes also include a more efficient use of energy substrates supplied with diet and their effective metabolism, as well as a more pronounced activation of anaerobic processes and an increase in buffer capacity of the blood (Górski, 2006). In this study, the significant effect of training in athletes competing in the $400 \mathrm{~m} / 400 \mathrm{~m}$ hurdles races on the values of the muscle and adipose tissue content, but also on the maximum power, mean power and exerted work parameters, was confirmed. This may indicate a good preparation for the applied exercise load in subjects, which in turn allows obtaining better results in sprints. The above changes directly contribute to an increase in the maximum power index in the first few seconds of physical exercise, a longer-lasting peak value of the index and a milder decrease at the end of the cardiac stress test performed.

\section{Effect of repeated speed exercise on the parameters describing anaerobic endurance}

In athletes participating in the three repeated, 12-second cardiac stress tests at a supramaximal intensity, changes in the obtained maximum power values were observed. A tendency of the maximum power value to 
decrease compared to the previous results obtained in cardiac stress tests was observed in the studied athletes. In the studies conducted by Watt et al. (Watt, Hopkins, Snow, 2002) involving the assessment of the results of repeated cycloergometric tests, obtained in a double 30-second Wingate test with a 4-minute interval between the runs, a significant decrease in the values of maximum and mean power was observed. In this study, applying shorter exercise and longer intervals might have contributed to the lack of significant changes in the obtained parameters of maximum and mean power. During a cardiac stress test, loss of energy resources occurs in the phosphagenic and anaerobic/aerobic glycolytic processes.

The loss of energy substrates in the aforementioned processes leads to a rapid activation of reactions aimed at the recovery of the resources (Weber, 2002). The ability of a quick regeneration might be the cause of maintaining high maximum and mean power indices in the repeated anaerobic endurance test. In a cardiac stress test lasting 30 seconds or longer, it is impossible for the body to fully rebuild the depleted energy resources during an interval between the runs that lasts a few minutes, due to the large amount of resources that are lost. Studies confirming this observation are, e.g., those conducted by (Parra, Cadefau, Rodas, Amigo, Cusso, 2000) in which, by using muscle biopsy, a significant post-exercise decrease in the concentrations of phosphocreatine $(\mathrm{PCr})$ and an increase in the levels of creatine $(\mathrm{Cr})$ were observed in the muscle after a 30-second Wingate test. In this study, the progressive decrease in the values of maximum and mean power in 5 athletes, with a concurrent lack of such correlation in 2 subjects, resulted in a decrease exclusively in the aforementioned parameters in the studied group. In order to elucidate the differences in the values of the power generated during repeated speed exercise, an assessment of acid-base balance and glucose accessibility for the resynthesis of energy resources was performed.

\section{Effect of hiochemical processes on the ability of anaerobic exercise}

The repeated exercise at a supramaximal intensity performed during the study significantly contributed to the disturbance of homoeostasis in each athlete from the beginning of the first test run. The post-exercise values of all three measured parameters: glucose levels, acid-base balance of the blood and lactate levels, demonstrated significant differences compared to the baseline values. The biochemical measurements conducted during the cardiac stress tests revealed strict correlations between selected parameters and the results of the ergometric tests obtained by the athletes.

\section{Changes in blood glucose levels and the ability of anaerobic exercise}

In the first phase of speed exercise, the body uses energy obtained in the anaerobic/lactate-independent processes, in which no significant differences in blood glucose levels are observed. However, the activity of the autonomic nervous system is increased, which affects the physiology of the sympathetic nervous system during intense physical activity, leading to the activation of adrenalin, noradrenalin and glucagon production and the subsequent increase in their concentrations. These three hormones increase glycogenolysis activation in the liver and muscles in which glucose is stored in the form of glycogen (Czajkowska-Pączek, Przybylski, 2006). Thanks to the presence of the aforementioned hormones and the process of glycogenolysis, glycogen is converted into glucose whose increased blood levels are detectable after only 10-20 seconds from the start of speed exercise (Gabryś, 2000). Such changes were confirmed in the conducted study, and what is more, an increase in blood glucose levels was found after each test run. Moreover, the observed uniform increase in blood glucose levels may 
suggest a high efficiency of the glycolytic processes in the athletes, which may have a direct influence on passing the race distance more effectively.

\section{Changes in blood lactate levels and the ability of anaerobic exercise}

Anaerobic glycolysis used to balance the energetic demands of the muscles leads to the release of considerable amounts of lactate. The compound is produced in the process due to the accumulation of pyruvate, which, in the absence of oxygen and in the presence of lactate dehydrogenase, is converted into lactate. High intensity exercise along with a large number of fast twitch muscle fibres involved result in a significant increase in lactate blood levels (Kin-Isler, 2006; Özturk, Özer, Gokce, 1998). Indeed, in the conducted experiment, a significant increase in lactate blood levels was observed. The course of the process was identical in the post-exercise period in all subjects, either after the first or every further test run. Increased blood lactate levels exert specific effects in the muscles, whose symptom is an increasing fatigue of the athlete marked by a tendency of the maximum and mean power values to decline in the study. Moreover, this observation is also a proof of high utilization of the glycolytic potential in the athletes, although the obtained lactate levels were not as high as those accompanying supramaximal exercise in sprints. Additionally, it is important to determine the parameter of acid-base balance in order to precisely monitor muscle homoeostasis in the conducted study.

\section{Changes in acid-base balance and the ability of anaerobic exercise}

Lactate levels are the main parameter affecting the acid-base balance in the setting of anaerobic exercise. Increased lactate levels cause a proportional decrease in bicarbonate levels and the activation of buffer reactions in the body, aimed at reducing the growing systemic acidification (Hennessey, 2008; Konturek, Brzozowski, 2003). In people with a high level of training in speed disciplines, no changes in the resting values of blood acid-base balance occur, which was also confirmed by the results of this study. The lack of a significant decrease in maximum and mean power might therefore be caused by the increased tolerance to systemic acidification via an increased buffer capacity of the muscles and a quicker recovery from the occurring deviation from the reference values. The more buffering bases are used, the better the capacity of acidification neutralization via hydrogen ion binding in the muscles is. Undoubtedly, it is affected by an increased capillary growth in the muscles, caused by muscle hypertrophy occurring as an adaptive reaction to specific training loads.

\section{Conclusions}

1. Training conducted by athletes competing in the $400 \mathrm{~m} / 400 \mathrm{~m}$ hurdles races allows them to obtain high values of maximum anaerobic power.

2. Performing repeated supramaximal exercise by the subjects did not significantly affect the values of maximum and mean power.

3. A strict correlation was observed between the obtained values of maximum and mean power during repeated supramaximal exercise.

4. Repeated supramaximal exercise induces a decrease in the value of blood acid-base balance, as well as blood lactate and glucose levels.

5. Performing repeated supramaximal exercise by the subjects leads to an increase in systolic blood pressure and a decrease in diastolic blood pressure. 


\section{References}

Bar-Or, O., Dotan, R., Inbar, O. (1997). A 30 sec all-out ergometric test: Its valiability and validity for anaerobic capacity. Israel J Med Scs, 326-327.

Bar-Or, O., Inbar, O., Skinder, J.S. (1996). The Wingate anaerobic test. Human Kinetics, 1-40.

Boobis, L., Cheetham, M. (1986). Human muscle metabolizm during sprint running. Journal App Physiol, 54-60.

Czajkowska-Pączek, B., Przybylski, J. (2006). Zarys fizjologii wysiłku fizycznego. Wydawnictwo Medyczne Urban \& Partner, 68-74.

Gabryś, T. (2000). Wydolność beztlenowa sportowców. Katowice: Wydawnictwo AWF w Katowicach.

Gabryś, T., Szmatlan-Gabryś, U. (1997). Specyfika wydolności beztlenowej lekkoatletów ocenianej 30-sekundowym ergometrycznym testem mocy. Trening, 1-3.

Górski, J. (2006). Fizjologiczne podstawy wysiłku fizycznego. Wydawnictwo Lekarskie PZWL.

Greenhaff, P., Hultman, E., Harris, R.C. (1993). Carbohydrate metabolism. Principles of exercise biochemistry, 5-8.

Heck, H., Schulz, H., Bartmus, U. (2003). Diagnostics of anaerobic power and capacity. Eur J Sport Scs, 2-20.

Hennessey, I. (2008). Gazometria krwi tętniczej. Elsevier Urban \& Partner, 4-12.

Iskra, J. (2001). Morfologiczne i funkcjonalne uwarunkowania rezultatów w biegach przez płotki. Katowice: Wydawnictwo Akademii Wychowania Fizycznego w Katowicach.

Jaskólska, A., Jaskólski, A. (2006). Podstawy fizjologii wysiłku fizycznego z zarysem fizjologii człowieka. Wrocław: Wydawnictwo AWF Wrocław.

Kin-Isler, A. (2006). Time-of-day effects in maximal anaerobic performance and blood lactate concentration during and after a supramaximal exercise. Isokinetics and Exercise Science, 335-340.

Konturek, S., Brzozowski, T. (2003). Fizjologia człowieka. Kraków: Wydawnictwo UJ Kraków.

Kosendiak, J., Habiniak, M., Markowski, T. (1999). Wykorzystanie 30-sekundowego testu Wingate do oceny zmian poziomu wydolności beztlenowej sprinterów. Sport Wyczynowy, 24-26.

Kozłowski, S., Nazar, K. (1995). Wprowadzenie do fizjologii klinicznej. Wydawnictwo Lekarskie PZWL.

Kubica, R. (1995). Podstawy fizjologii pracy i wydolności fizycznej. Kraków: AWF.

Malarecki, J. (1981). Zarys fizjologii wysiłku i treningu sportowego. Warszawa: Wydawnictwo Lekarskie PZWL.

Özturk, M., Özer, K., Gokce, E. (1998). Evaluation of blood lactate in young men after wingate anaerobic power test. Eastern Journal of Medicine, 13-16.

Parra, J., Cadefau, A., Rodas, G., Amigo, N., Cusso, R. (2000). The distribution of rest periods affects performance and adaptations of energy metabolism induced by high-intensity training in human muscle. Acta Physiol Scand, 157-165.

Traczyk, W.Z. (2002). Fizjologia człowieka w zarysie. Wydawnictwo Lekarskie PZWL.

Watt, K.K.O., Hopkins, W.G., Snow, R.J. (2002). Reliability Of performance in repeated sprint cycling tests. Journal of Science and Medicine in Sport, 354-361.

Weber, C.L. (2002). Metabolic responses to supramaximal exercise and training a gender comparison. School Of Physiotherapy and Excercise Science, 12-16.

Wołkow, N.I., Jarużnyj, N.W. (1986). Zakonomiernosti biochimiczeskoj adaptacji w processje sportiwnoj trenirowki. GCOLIFK Moskwa, $18-20$.

Zając, A., Wilk, M., Poprzęcki, S., Bacik, B. (2009). Współczesny trening siły mięśniowej. Katowice: Wydawnictwo AWF Katowice.

Cite thil article aS: Stolecka-Warzecha, A., Kaczmarczyk, T., Żebrowska, A. (2016). Assessment of Anaerobic Endurance Based on Selected Biochemical Parameters in $400 \mathrm{~m} / 400 \mathrm{~m}$ Hurdles Male Athletes. Central European Journal of Sport Sciences and Medicine, 14 (2), 101-110. DOI: 10.18276/cej.2016.2-12. 